\title{
Study of Sedation, Pre-anesthetic and Anti-anxiety Effects of Salix Aegyptiaca Herbal Extract in Comparison with Diazepam in Rats
}

\author{
Ali Razaei ${ }^{1}$, Sajjd Moghaddam ${ }^{2}$, Mehrdad Pashazadeh $^{3}$, Arvin Tayari $^{4}$, \\ Ehsan Sanati ${ }^{5}$ \\ ${ }^{\text {I}(D e p a r t m e n t ~ o f ~ C l i n i c a l ~ S c i e n c e s, ~ F a c u l t y o f ~ V e t e r i n a r y ~ M e d i c i n e, ~ I s l a m i c ~ A z a d ~ U n i v e r s i t y, ~ T a b r i z B r a n c h, ~}$ \\ Tabriz, Iran) \\ ${ }^{2}$ (expert group of Biology, Islamic Azad University of Ahar-Iran) \\ ${ }^{3}$ (Young researchers and EliteClub, Ahar Branch, Islamic Azad University, Ahar-Iran) \\ ${ }_{4}^{4}$ (Young researchers and EliteClub, Tabriz Branch, Islamic Azad University, Tabriz-Iran) \\ ${ }_{5}^{5}$ (Department of Histology \& Embryology science, Tehran Branch, Islamic Azad University, Tehran-Iran)
}

\begin{abstract}
Europe traditional medicine and most countries have had a special status and also in Iran since ancient is used as herbal extract, as well as salix extract has many therapeutic properties. Because this plant hasmany alkaloids, phenols andflavonoidsare constantly used for reducing the nerve pressure, treatment of chronic insomnia, depression, create a calming effect and appealed to the restoration of skin. With noticeof synthetic drugsside effects and economic issues we sensed to need that to compare of anti-anxiety and pre anesthetic effects of the extracts of this plant with the synthetic drugs. Methods: In different groups of Wistar male rats, the extract ofSalix Aegyptiacawith doses of $100 \mathrm{mg} / \mathrm{kg}, 200 \mathrm{mg} / \mathrm{kg}$ and $400 \mathrm{mg} / \mathrm{kg}$ and diazepam with $1.2 \mathrm{mg} / \mathrm{kg}$ were injected andDimethyl sulfoxide with the same volume 30 minutes prior to the assessment of the effects of sedation and anesthesia (sleeping period induced with ketamine) with the dose of $40 \mathrm{mg} / \mathrm{kg}$ was injected and for evaluating of the anti-anxiety effects "Elevated plus maze" was used. Results: The achieved results represent a significant increase for sleeping that induced by ketamine, as well as a significant increase in the time expired in the open arms in the treated group with $200 \mathrm{mg} / \mathrm{kg}$ of extract.Conclusion: The results showed that the salixextract with a dose of $200 \mathrm{mg} / \mathrm{kg}$ has the effects of pre-anesthesia, and anti-anxiety.
\end{abstract}

Keywords:Anti-anxiety, Diazepam, Elevated plus maze, SalixAegyptiaca, Sedative.

\section{Introduction}

Nowadays, medicinal plants make an important part of traditional medicine in most of the countries, and in the establishment of the therapeutic value of new approacheshas a special place. In this study, which has been trying that this extract as an anti-anxiety andpre-anesthetic drugwith better efficacy and fewer side effects than a synthetic drug be introduce[1].This plantis known with the scientific name of Salix aegyptiacaand that's extract maked by petals of the plant, which contains 200 types variescompositionsand 30 of them have known. This plant is mainly cultivated in Europe and the United States for industrial [2].In some areas of Iran such as Azerbaijan it grows well,the extract of that has dark brown color with bitter tasteand penetrating smell.The major material it consists of:carovone,phenolic flavonoids (16\%), carvacrol(9\%), cedreneoxide (16\%), Geranol $(10 \%)$, citronellol (4\%), p-metoxybenzene (2.3\%)[3]. This extract is available to absorb from the skin and mucosal membrane and it almost is completely absorbed from the digestive tract, and some of that is disintegrated here and metabolized in liver and some also is excreted by urinary system.the extract of Salix is depressor of sympathetic system activity and multiplier of Parasympathetic [4,5]. Another of its properties has been mentioned are anti-depressant effect, skin repair and sedationand also it can be used in topical method on way of skin and oral methods.Diazepam is type ofbenzodiazepinethat it's connected to molecular components of GABA-A receptor in membrane of the central nervous systemand leads to the opening of the chlorine Canal, thus it makes sedation and relaxationof muscles effects. The aim of this study is more discovering of a sedation and anti-anxiety effects of Salix extract and compare it with Diazepam as astandard sedative drug [6, 7].

\section{Methods}

In the present study, 30 Wistar male rats of $200 \pm 20 \mathrm{~g}$ weighting and about 3 month aged were used for laboratory experiments. Animals were kept in standard condition, at $20-25^{\circ} \mathrm{C}, 70 \%$ humidity and light cycle of 12 hours lighting and 12 hours darkness. Standard foods were used in order to feeding by method of Ad-Libitum in during 24 hours feeding. Specific dishes were used for water. It should be noted in order to adapt the rats with new environments, 10 days before the testing the rats were moved from Center of rats reproduction and 
breedingof School of medicine at Tabriz University to animals laboratory place of Islamic Azad University of Ahar. To prepare extract of the plant, the petals were used, tothis end1000 grams of dried herb were powdered, and in mixed chloroform: methanol (70:30) was soaked at least for 24 hours, and then obtained mixture under vacuum pressure in the rotary operator machine was removed solventto have earned raw extract [8]. The crude extract obtained heated in the least amount methanol and then within the freezer decreased to $-15^{\circ} \mathrm{C}$ temperature and quickly was smooth to get fatless extract,also in order to remove of water, the fat removed extract was solved in di-chloromethane and was dried with magnesium sulphateand in the rotary operator machine under vacuum was removed solvent to get pure extract. In order to study of pre-anesthesia and sedation effects of Salix herb extract in comparisonwith diazepam in the first group extract with dose of $100 \mathrm{mg} / \mathrm{kg}$, in the second group the extract with dose of $200 \mathrm{mg} / \mathrm{kg}$, in the third group the extract with dose of $400 \mathrm{mg} / \mathrm{kg}$, in the forth group diazepam with dose of $1.2 \mathrm{mg} / \mathrm{kg}$ and in fifth group di-methylsulfoxide in the same volume were injected by intra peritoneal and in the sixth group wasn't injected any drugs.30 minutes after administration of the above medications, ketamine with a dose of $40 \mathrm{mg} / \mathrm{kg}$ were administered by intraperitoneal to each of sixgroups. Immediately after administration of ketamine, the amount of time that an animal losses corrector reflexes (duration of anesthesia induction) and the amount of time that an animal, after induction of anesthesia,gains again the corrector reflexes (Duration of anesthesia) were calculated by seconds. In the second part of the study the aim is evaluating of the anti-anxiety effect of the drug. Elevated Plus Maze test consists of two open arms in front of each other in sizeof $(10 \times 50 \mathrm{~cm})$ and two enclosed armsin front of each other in size of $(40 \times 10 \times 50$ $\mathrm{cm})$ that by a central page $(10 \times 10 \mathrm{~cm})$ are connected together and this set is located in a relative dark and silent room with $50 \mathrm{~cm}$ altitudefrom the Earth. The time of testing the rat is put slowly and cautiously on the central part of the device so that the head of the rat is toward the open side, and for five minutes the number of went back to the inside of the arms and the period of staying on open arms were recorded and after every time of using of this device, it was cleanedby a cloth dipped in alcohol.Then the drugs were therefore listed as prescribed doses were administrated, and 30 minutes later, the rats For lonely, in the center of the maze, were put and the times that the rats spent in each of the maze arms were recorded in terms of seconds with a chronometer.The duration of the presence rats in the center of the maze and opened arms is considered as a markerof the lack of anxiety and the duration of the presence of rats on the enclosed arms is considered as a marker of anxiety. So increasing of duration, related to open arms, shows that the intended drug has the stronger anti-anxiety effect.

\section{Findings}

According to Fig.1, the Salix extract with dose of $200 \mathrm{mg} / \mathrm{kg}$ has less anesthesia induction time duration than diazepam, and the difference in the level of $(\mathrm{p} \leq 0.01)$ is significant.According to diagram 2 , theSalix extract with dose of $200 \mathrm{mg} / \mathrm{kg}$ has more anesthesia duration than diazepam andall differences are significant in statistically $(\mathrm{p} \leq 0.01)$. According to diagram 3, the Salix extract with dose of $200 \mathrm{mg} / \mathrm{kg}$ has the most effect as a anti-anxiety agent and all differences are significant in statistically $(\mathrm{p} \leq 0.01)$.

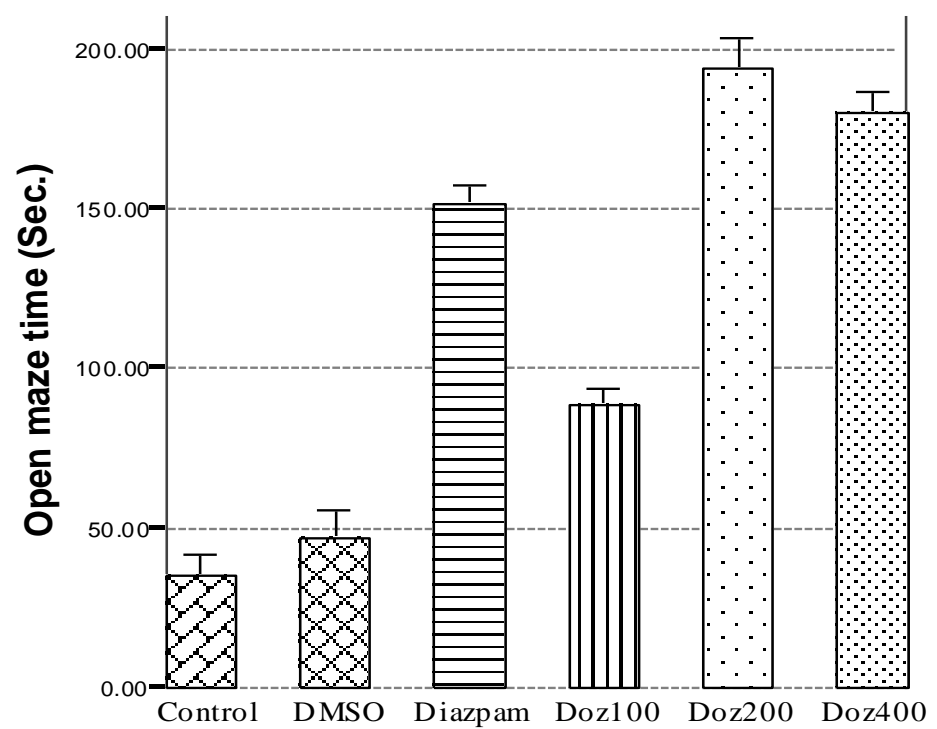

Fig.(1) Induction Time in study groups, according to the above chart, the dose of $200 \mathrm{mg} / \mathrm{kg}$ of Salixaegyptiaca has less Induction Time than the diazepam and all differences are significant in statistically $(\mathrm{p} \leq 0.01)$. 


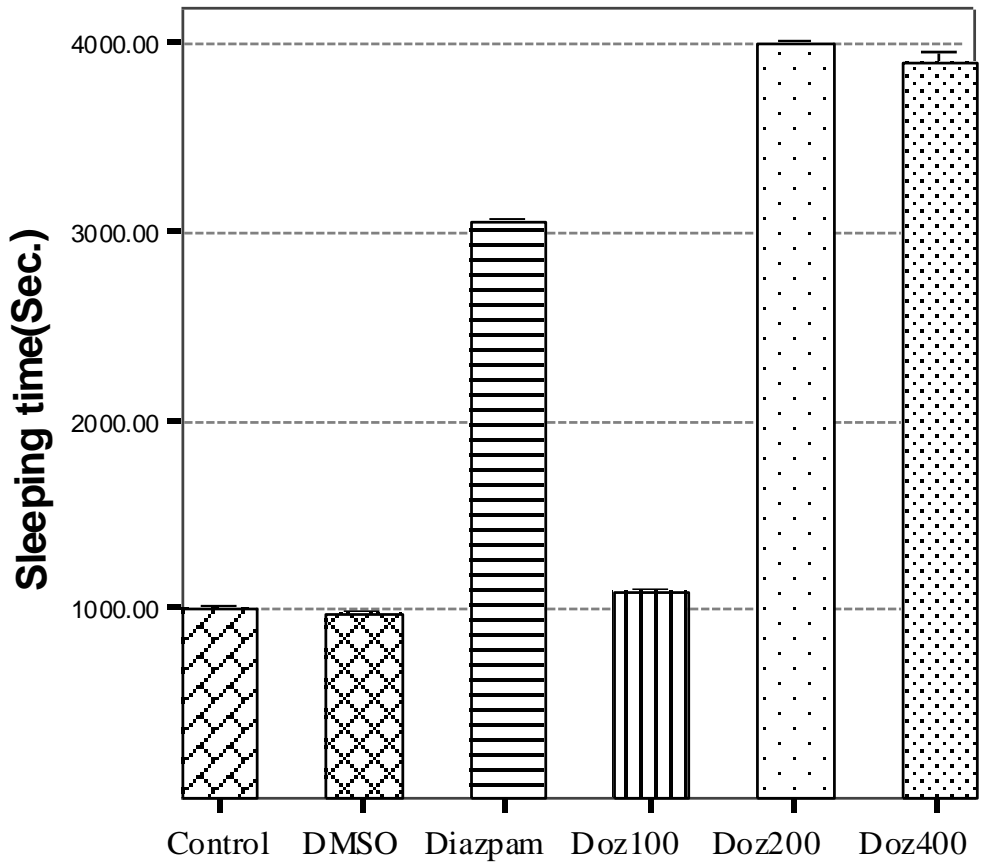

Group

Fig.(2) Sleeping Time in study groups, according to the above chart, the dose of $200 \mathrm{mg} / \mathrm{kgof}$ Salixaegyptiacahasless Time Sleeping than to diazepam and all differences are significant in statistically (

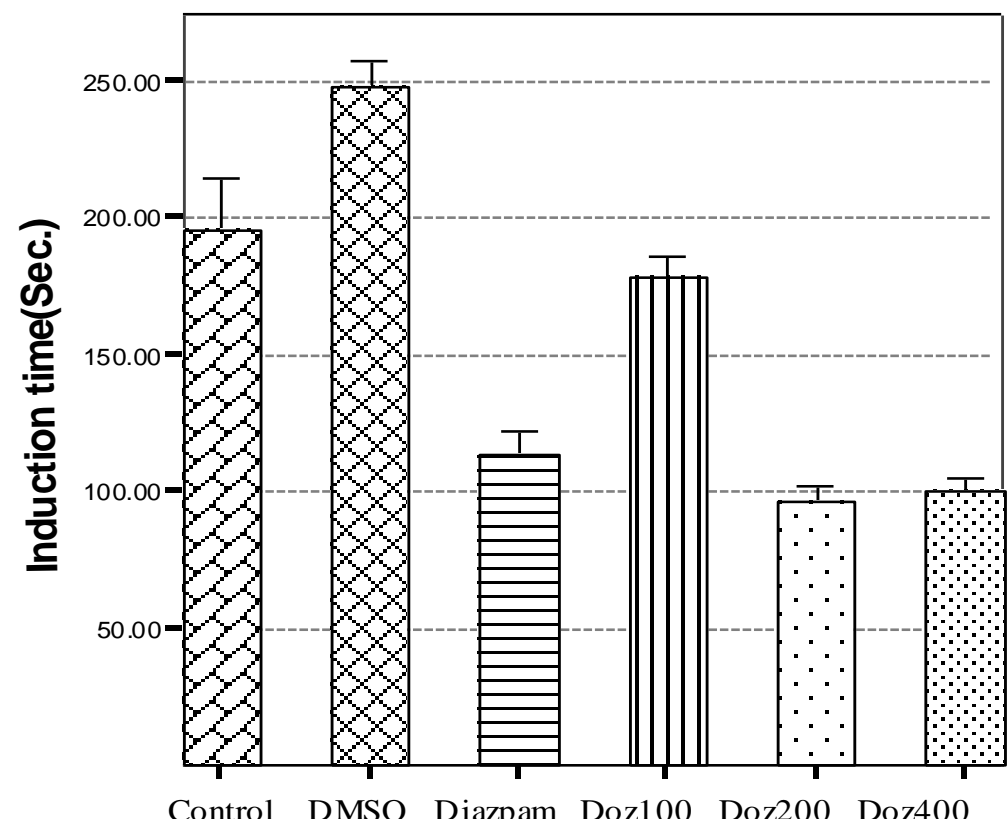

Group

$\mathrm{p} \leq 0.01)$.

Fig.(3)Open Maze Time in study groups, according to the above chart, the dose of $200 \mathrm{mg} / \mathrm{kg}$ of Salix aegyptiaca has rather Time open maze than the diazepam and all differences are significant in statistically ( $\mathrm{p} \leq 0.01)$.

\section{Discussion}

The purpose of this studyis survey of sedation, pre-anesthetic and anti-anxiety effects of Salix extract in comparison with diazepam in rats. Different compounds in the herb Salixaegyptiacahas been identified as follows: citronellol, 1, 4-Dimethoxybenzene, phenylethyl alcohol, 2-phenylethyl acetate. These factors increase the probability affectof this plant on different areas in CNS. Reports arebased on the influence of flavonoids on the benzodiazepine receptors [9]. According to being flavonoids in this plant,the probability that Salix extract by 
affect of the benzodiazepine receptors bound to the GABA-A receptors, causes sedation and anti-anxietyeffect is enhanced.Using of Salix aegyptiaca herb extract had been current in the middle ages for treatmentof depression $[10,11]$. This extract as a benzodiazepine drughas a proven effects on the central nervous system and the other sideit's mentioned as an anti-anxiety drug. Diazepam via interactions with the GABA receptors in the brain, especially in lattice structure in Middle brain, cause effects of sedation and anti-anxiety. The results showed that during the reviews of the sedation, in between of the doses used, the dose of $200 \mathrm{mg} / \mathrm{kg}$ body weight had more significant responses than other doses of extract in comparison with diazepam $(\mathrm{p} \leq 0.01)$.in this research to get the appropriate dose, in experimentally some doses were used(100, 200 and $400 \mathrm{mg} / \mathrm{kg}$ ), based on achieved results Salixaegyptiacaextract in dose of $200 \mathrm{mg} / \mathrm{kg}$ has less anesthetic induction and moreanesthetic duration than diazepam with dose of $1.2 \mathrm{mg} / \mathrm{kg}$ and it hasmore significant responses in comparison with other doses of extract in contrast of diazepam $(\mathrm{p} \leq 0.01)[12,13]$. In other words, it has the better pre-anesthetic and sedative effects in comparison withdiazepam.Salix extract in doses of 100 and $400 \mathrm{mg} / \mathrm{kg}$ body weight has weaker sedative and pre-anesthetic effects in comparison with diazepam. In another part of the study the anti-anxiety effect of diazepam was surveyed that the based on achieved results the Salix extract in dose of $200 \mathrm{mg} / \mathrm{kg}$ makes stronger anti-anxiety effect in comparison with diazepam in dose of $1.2 \mathrm{mg} / \mathrm{kg}$, also the extract in this dose makes decreaseof mobility balance.It can be concluded from the present study that the injection of Salix extractin dose of $200 \mathrm{mg} / \mathrm{kg}$ by intraperitoneal as a pre-anesthetic medication before of ketamine injection makes less anesthetic induction period and more duration of anesthesia than diazepam in dose of $1.2 \mathrm{mg} / \mathrm{kg}$, and it shows significant difference $(\mathrm{p} \leq 0.01)$ [14]. As well as the injection of Salix extract in dose of $200 \mathrm{mg} / \mathrm{kg}$ by intraperitoneal in order to evaluate the anti-anxiety effects makesthe increase ofstaying time on the open armsof the maze device and makes better effects in comparison with diazepamand shows a significant difference $(p \leq 0.01)$. Therefore, due to the existence of flavonoids in Salix extract, it is probablythat this plant via effect on benzodiazepine receptors bound to GABA-A receptors causes sedation and anti-anxiety effects [15].

\section{References}

[1]. M. Rabbani, G. Vaseghi, SE. Sajjadi, B. Amin, Persian Herbal Medicines with Anxiolytic Properties, J. Med. Plants, 10(39), 2011, 7-11.

[2]. AA. Maassoumi, Experimental taxonomy of the genus SalixL. (Salicaceae) in Iran, Iran. J. Bot, 15(1), 2009, 3-20.

[3]. I. Karimi, H. Hayatgheybi, T. Shamspur, A. Kamalak, M .Pooyanmehr, Y. Marandi, Chemical composition and effect of an essential oil of Salix aegyptiaca (musk willow) in hypercholesterolemic rabbit model, Braz. J. Pharmacog, 21(3), 2011, $407-414$.

[4]. GW. Argus , Salix distribution maps and synopsis of their classification in North America, north of Mexico,Harvard Papers in Botany, 12,2007, 335-368

[5]. JM. Mates, C. Perez-Gomez, I. Nunez de Castro, Antioxidant enzymes and human diseases, Clin.Biochem, 32, 1999, 595-603.

[6]. T. Kurosawa, F. Itoh, A. Nozaki, Y. Nakano, S. Katsuda, N. Osakabe, H. Tsubone, K. Kondo, H. Itakura, Suppressive effects of Cacao liquor polyphenols (CLP) on LDL oxidation and the development of atherosclerosis in Kurosawa and Kusanagihypercholesterolemic rabbits, Atherosclerosis, 179, 2005, 237-246.

[7]. S. Caccia, M.Gobbi ,St. John's Wort components and the brain, Uptake, concentrations reached and the mechanisms underlying pharmacological effects, Curr Drug Metab 10(9), 2009, 1055-65.

[8]. H. Hosseinzadeh, M. Nasseri, Anti convulsant sedative and muscle relaxant effects of carbenonlone in mice, BMC Pharmacol, 3(6), 2003, 72-81.

[9]. 9-S. Enayat, S. Banerjee, Comparative antioxidant activity of extracts from leaves, bark and catkins of Salix aegyptiaca,Food Chem, 116, 2009, 23-28.

[10]. F. Fang-Zhen,On the distribution and origin of Salixin the world,ActaPhytotax. Sinica, 25, 1987, $307-312$.

[11]. A. Hemati, M. Azarnia, AH.Angaji,Medicinal effects of Heracleumpersicum (Golpar),Middle-East J. Sci. Res.,5, 2010, 174-176.

[12]. H. Ohashi, A systematic enumeration of Japanese Salix (Salicaceae),J. Jpn. Bot.,75, 2000, 1-41.

[13]. M. Rabbani, SE. Sajjadi, F. Rahimi, Anxiolytic effect of flowers of Salix aegyptiacaL. in mouse model of anxiety,J. Complementary Integr. Med., 7(1), 2010, 18-22.

[14]. A. Sonboli, M. Mojarrad, S. NejadEbrahimi, S. Enayat, Free radical scavenging activity and total phenolic content of methanolic extracts from male inflorescence of Salix aegyptiacagrown in Iran, Iranian J. Pharmaceut. Res., 9(3), 2010, $293-296$.

[15]. K. Rezaei, R. Jebraeili, B. Delfan, M, Noorytajer, MH, Meshkat, H, Maturianpour. The effect of clove bud, Nigella and Salix albaon wart and comparison with conventional therapy, Eur. J. Sci. Res.,21, 2008, 444-450. 